\title{
Note about Cholesterol
}

\author{
J. Planer \\ Originally published in German in "Mittheilungen aus dem Universitätslaboratorium in Lemberg"; \\ Annalen der Chemie und Pharmacie (Annals of Chemistry and Pharmacy), Band CXVIII, \\ Bandes erstes Heft (Issue 1), 25-27, 1861. Copyright Willey-VCH Verlag GmbH \& Co. KGaA
}

Translation received June 1, 2010

A translation from German of the original paper by Prof. Planer in which he describes his observations of selective light reflection in monotropic cholesteric liquid crystal phase of cholesteryl chloride that he synthesized. Translation by Peter Oelschlaeger, Chemistry Department and Center for Macromolecular Modeling and Material Design and by Hector Cordova Mireles, Department of Physics, both from the California State Polytechnic University at Pomona. Translation was slightly revised by Prof. H.S. Kitzerow, Department of Chemistry from the University of Paderborn in Germany. Reproduced with the permission of Willey-VCH Verlag GmbH \& Co. KGaA.

Key words: cholesteryl chloride, monotropic cholesteric liquid crystal phase

PACS: $61.30 .-v, 64.70 . p v, 82.70 . D d$
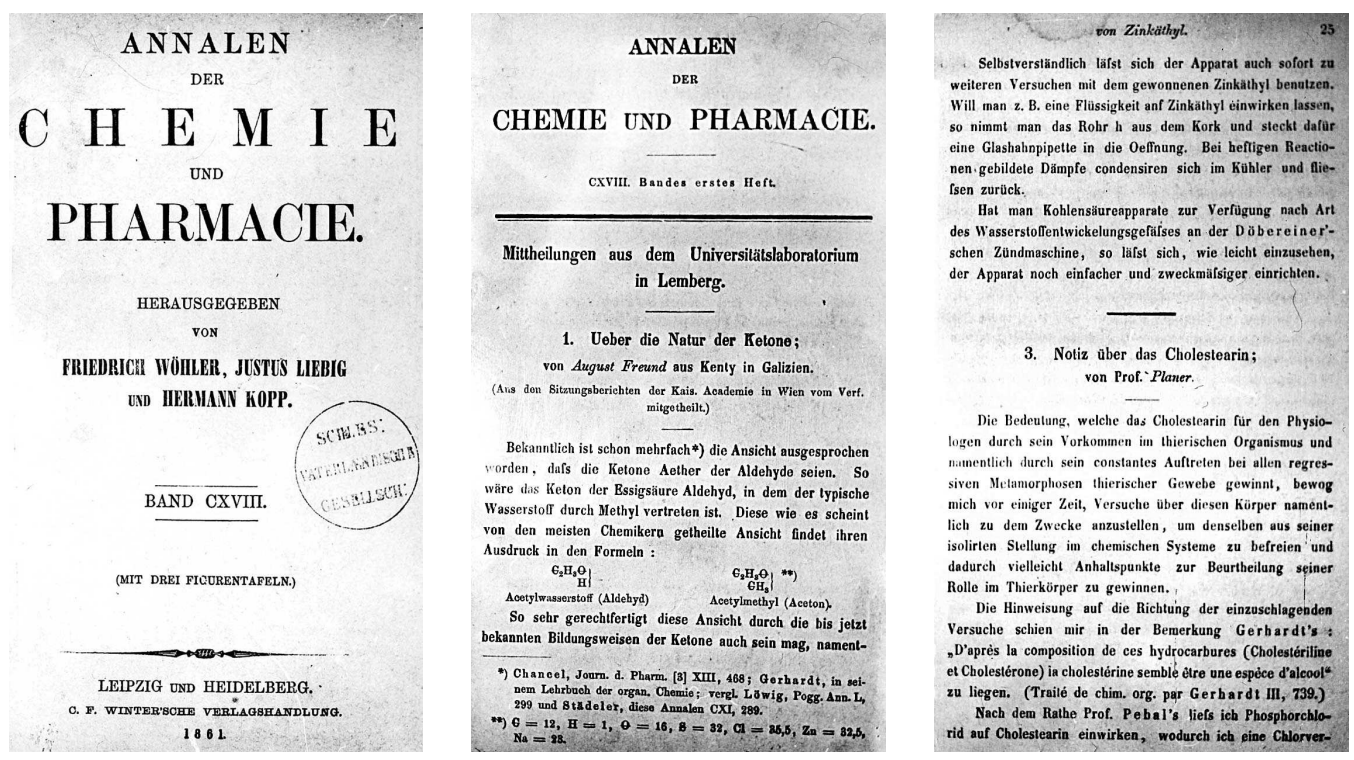

The significance that cholesterol gains for the physiologist due to its presence in the animal organism and namely due to its constant appearance in all regressive metamorphoses of animal tissue, moved me a while ago to conduct experiments on this body substance, namely in order to liberate it from its isolated position in the chemical system and to thereby possibly obtain clues for the judgment of its role in the animal body.

The guidance for the direction of the experiments for me to conduct seemed to lie in the comment by Gerhardt: "After the composition of these hydrocarbons (cholesterol and cholesterone), cholesterol seems to be an alcohol" [original in French] (Traite de chim. org. par Gerhardt III, 739.)

*At present Lviv, Ukraine. 
Following the advice of Prof. Pebal, I let phosphorus trichloride act on cholesterol, by which I obtained a chlorine compound of cholesterol, which I wanted to use to synthesize other derivatives of the alcohols of analogous compounds of cholesterol. While I was working at these experiments, Berthelot's note appeared in the Compt. rend. 47: "About several new alcohols", after which I stopped the continuation of my experiments.

However, from the detailed work of Berthelot, which appeared in Ann. ch. phys. 112, 356, I see that the chlorine cholesteryl synthesized in my way is a very different compound than the one that Berthelot obtained by heating hydrochloric acid and cholesterol in a fused tube, which he describes as a non-crystalizable, transparent, resinlike substance, whose chlorine content constantly decreases. This prompts me to call attention to the cholesteryl prepared by me, namely because this compound is quite suitable for the exact determination of the formula of cholesterol and could probably also successfully be used as a starting point for the synthesis of other compounds of this body substance.

The action of phosphorous trichloride already proceeds quite actively at room temperature; one obtains a brown, viscous substance, which soon solidifies in crystals and which can easily be purified by squeezing, repeated boiling in water and recrystallization in ether/alcohol. At slow crystallization from alcohol chlorocholesteryl forms long needle-shaped crystals, at slow crystallization from ether ether/alcohol a crumby crystal paste; those dissolve easily in ether and hardly in wine spirit, contain no crystal water, melt roughly at the boiling point of water; during the cooling process, the molten substance exhibits a lively violet color in incident light, a yellow-green color in transmitted light; when cooling is complete, it adopts a crystalline consistency again. The compound is very hard to decompose; even boiling in concentrated caustic potash does not change it.

Since the preliminary analyses of the substance of different preparations yielded numbers, from which the constant composition of the substance emerges, I am presenting these here. The combustions were done with chrome acidic lead, for the chlorine determination the substance was destroyed with potash lime.

I. 0.439 substance gave $1.287 \mathrm{CO} 2$ and $0.4425 \mathrm{HO}$.

II. 0.448 (of another preparation) $1.308 \mathrm{CO} 2$ and $0.4505 \mathrm{HO}$.

III. 0.540 substance yielded $0.1904 \mathrm{AgCl}$.

IV. 0.613 substance yielded $0.2122 \mathrm{AgCl}$.

From the obtained numbers the calculated numbers for 100 parts are:

\begin{tabular}{ccccccc} 
& I. & II. & III. & IV. & \multicolumn{2}{c}{ calculated } \\
$\mathrm{C}$ & 79.95 & 79.62 & - & - & $\mathrm{C}_{32}$ & 79.89 \\
$\mathrm{H}$ & 11.19 & 11.17 & - & - & $\mathrm{H}_{43}$ & 11.01 \\
$\mathrm{Cl}$ & - & - & 8.71 & 8.55 & $\mathrm{Cl}$ & 9.09
\end{tabular}

\title{
Замітка про холестерол
}

\section{Ю. Планер}

Оригінал статті був опублікований німецькою мовою у “Доповідях з університетських лабораторій у Лемберзі", Annalen der Chemie und Pharmacie, том. 118, вип. 1, ст. 25-27, 1861.

\begin{abstract}
Переклад з німецької оригінальної статті проф. Планера, в якій він описує вибіркове відбивання світла в синтезованій ним монотропній рідкокристалічній фазі хлориду холистеролу. Переклад зроблено Пітером Оелшлагером та Гектором Кордова-Моралесом з Каліфорнійського університету в Помоні. Переклад був підкорегований професором Кітзеровим з Падеборнського університету в Німеччині. Публікується з дозволу Willey-VCH Verlag GmbH \& Co. KGaA.
\end{abstract}

Ключові слова: хлорид холестерилу, монотропна холестерична рідкокристалічна фаза 